\title{
The changing union and bargaining landscape: union concentration and collective bargaining trends
}

\section{Bernhard Ebbinghaus}

\begin{abstract}
Unions in Western Europe have tended to merge in larger organisations, straddling across traditional bargaining demarcations. Despite the trend towards union concentration, cross-national differences remain in the degree of fragmentation and the balance across private and public sectors. In the past years, wage moderation was common to nearly all bargaining systems, partly as a result of coordinated incomes policies or pattern-setting wage settlements. Tripartite concertation has proven more difficult because of increased dissatisfaction with modest pay increases and insufficient employment effects.
\end{abstract}

\section{Article by an MPIfG researcher}

Bernhard Ebbinghaus: The Changing Union and Bargaining Landscape: Union Concentration and Collective Bargaining Trends. In: Industrial Relations Journal 35(6), 574 - 587 (2004). Wiley-Blackwell

The original publication is available at the publisher's web site: http://dx.doi.org/10.1111/j.1468-2338.2004.00334.x

The main role of trade unions is to regulate the pay and working conditions of employees, although they have had to face considerable obstacles in recent years in negotiating collective agreements even on behalf of their members. Since the 1980s, pressures towards the decentralisation of collective bargaining, greater flexibility of employment contracts and the deregulation of labour markets have proven to be major challenges to traditional economy-wide or even sector-wide bargaining. The margin for wage increases shrank because of an increasingly adverse economic situation; mass unemployment since the first oil shock of 1973; the change from Keynesian demandside to neo-liberal supply-side economic policies; the increased pressure on competitiveness given growing European integration and internationalisation; and the Europeanisation of monetary policy, particularly through European Monetary and Economic Union (EMU). Nevertheless, the 1990s also witnessed a resurgence of tripartite social pacts in some European countries in response to economic pressures, in particular the need for economic adjustments and welfare state reforms in the runup to and consequences of EMU (Molina and Rhodes, 2002; Rhodes, 2001). In contrast to the neo-corporatist incomes policies of the 1960s and 1970s, the new social pacts seemed less dependent on centralised union movements and could not rely on favourable subsidies to employees through the welfare state (Ebbinghaus and Hassel, 2000). Whether the trend towards wage moderation that was seen as the hallmark of

$\square$ Bernhard Ebbinghaus is currently Visiting Professor at the University of Jena and Researcher at the Max Planck Institute for the Study of Societies. Correspondence should be addressed to Bernhard Ebbinghaus, Max Planck Institute for the Study of Societies, Paulstr. 3, D-50676 Cologne, Germany; email: ebbinghaus@mpi-fg-koeln.mpg.de 
the 1990s continues or not and whether this is because of bargaining coordination and organisational concentration are the topics of this article.

\section{THE CHANGING ORGANISATIONAL LANDSCAPE}

The weakening of collective bargaining in Europe has been addressed by unions in their attempts to reverse membership decline, mobilise their members and restructure their organisations. The stagnation in union membership and even decline in union density in most union movements across the EU-15, Norway and Switzerland (Ebbinghaus, 2002; Ebbinghaus and Visser, 2000) have been particular problems weakening unions at the bargaining table as they represent fewer workers with more diverse interests, mustering fewer financial resources and mobilising fewer workers in strike actions. Although the Nordic countries and Belgium have relatively stable and high union density, membership growth has reached its limits and a shift towards representing public sector and white-collar workers will continue to alter balances in interest representation. In the UK and Ireland, declining union density over two decades has weakened unions and forced them to consolidate union structures, while decentralisation pressures have been widespread, particularly in Britain (and especially in contrast to the Irish tripartite concertation process). Union membership decline in most Continental European countries has also put considerable pressure on union movements to pool resources via mergers. However, the remaining strength of large unions and the effect of a multi-employer bargaining system, as well as legal support for collective agreements, remain responsible for the relatively widespread coverage on the Continent in comparison to Britain (Traxler and Behrens, 2003).

As Table 1 indicates, many of the now-largest affiliates to union confederations were the result of large-scale mergers during the last two decades (for more details see Ebbinghaus, 2003). This was particularly the case not only in Britain and Ireland, Germany, the Netherlands and Switzerland, but also for Italian CISL and some Nordic union movements (Danish LO, Finnish SAK and STTK, Norwegian LO). As unions faced increasing problems in organising members and mobilising sufficient financial resources, organisational restructuring became a major strategy to adapt to a more adverse socio-economic and political environment (Waddington and Hoffmann, 2000). The tendency towards large general unions or multi-sector 'superunions' has increased the trend towards larger unions; this has repercussions for the power balances within union movements and the coordination problems across them. The largest affiliates increasingly dominate union confederations and are large enough to go it alone. Nevertheless, there are still important cross-national differences in the union landscape that provide different contexts for interest representation in general and collective bargaining in particular. Here, it is helpful to discuss the organisational developments in regional clusters (see Table 1): the Anglo-Irish, Nordic, the Northern Continental and then Southern Continental European development (see also Ebbinghaus, 2003).

Although several union mergers have led to major changes in the British and Irish union landscapes, the new super-unions are less dominant in a more fragmented union movement compared to some other Continental countries. A useful indicator of union concentration is the membership accounted for by the three largest unions. The three biggest British and Irish unions together do not exceed half of the total membership of their confederations, the Trades Union Congress (TUC) and the Irish Congress of 


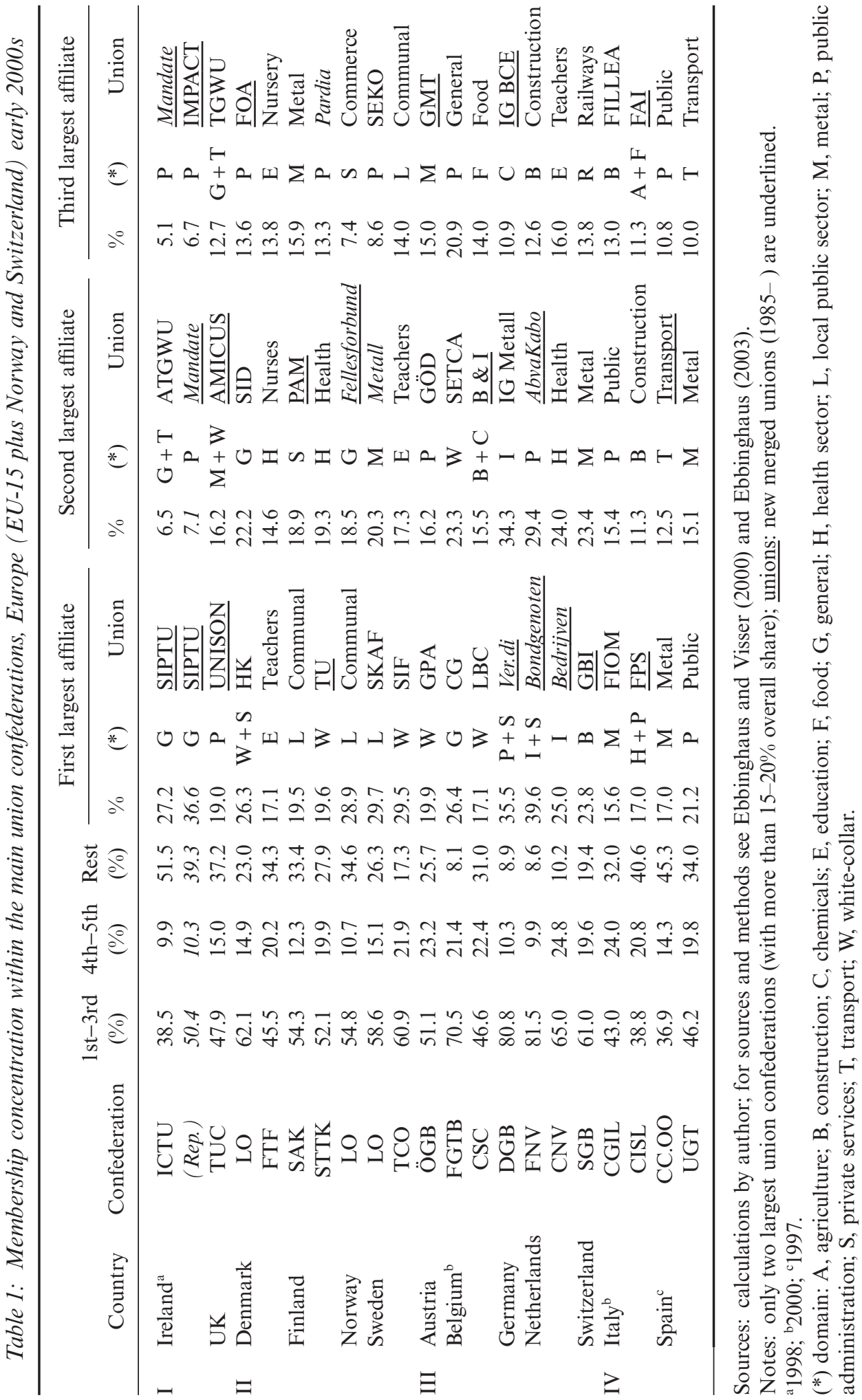


Trade Unions (ICTU). In contrast, most continental union movements, except for Southern Europe, do so. Furthermore, following merger waves over the last two decades, the second regional cluster of Nordic union movements - both the main bluecollar and white-collar unions - have become increasingly concentrated (above the per cent indicator), except for the Danish white-collar union FTF (45 per cent) and the smaller academic employee union centres. In particular, the Danish LO, Swedish LO and Swedish TCO are the most concentrated (around 60 per cent), although these union confederations have lost members in recent years, while the white-collar union centres have continued to grow. In addition to the impact of large unions, bargaining cartels of sectoral or occupational unions have facilitated the coordination at the negotiating table in Nordic countries (Kjellberg, 1998).

The trend towards super-unions has been most advanced in Germany and the Netherlands where the three largest unions now total more than 80 per cent of all membership within the main union confederations (the German DGB and Dutch FNV). A similar concentration will occur in Austria when the white-collar union GPA joins the metalworkers' union in 2005. Member organisations of the Belgian Socialist federation is also highly concentrated (70 per cent), followed by the Dutch Christian unions and Swiss union centres (60-65 per cent), while the large Belgian Christian union CSC/ACV has been less concentrated (45 per cent) because of language differences and the Belgian liberal union centre (CGSLB/ACLVB) decided to consolidate its internal sections in 2003.

In contrast to these unions, the union movements in France, Greece, Portugal and Spain are split not only in terms of political and other factors; internally, they are also fragmented. In Italy, while the largest unions in all three political union confederations are those of pensioners, those unions with active membership involved in collective bargaining are less concentrated (the largest three active unions organise less than 45 per cent). Similarly, in Spain the larger unions take up a less dominant role within the confederation. Hence, a tendency towards union concentration is most pronounced among the unitary union movements in Germany, Netherlands and Austria, thereby enhancing bargaining power and coordination, while the more politically divided union movements in Southern Europe are also more fragmented internally, making bargaining coordination cumbersome not only across rival union movements but also within its own camp.

Union concentration has had major repercussions for collective bargaining in Britain and Ireland. The other important influence stems from the restructuring and rebalancing of sectors and occupational groups represented by the most powerful unions within union movements. Because the public sector retains its significance in both countries, public sector unions play an important role in Britain, thus UNISON is the largest TUC union. In Ireland, general union SIPTU (Services Industrial Professional Technical Union) has 40 per cent of their members in the public sector, and the next largest Irish unions (Mandate, IMPACT) are public sector organisations. In addition, general unions straddle the private and public sectors, in particular the British TGWU (third in the TUC) and the Irish SIPTU (largest in the ICTU) and the new AMICUS (second in the TUC), the result of a merger of engineering and whitecollar unions in 2002.

Given the high union density across the large Nordic welfare states, the public sector unions play a prominent role. Communal workers' unions take the lead in the bluecollar union confederations of Finland, Norway and Sweden, with only the Danish LO an exception with its white-collar union HK as the largest affiliate. In addition, 
state employees' trade unions are major players as are the unions of health sector employees, teachers and kindergarten educators. In Norway, the communal and healthcare worker unions formed Fagforbundet in June 2003, increasing the distance to the second largest affiliate within the Norwegian LO, the blue-collar multi-sector union Fellesforbundet that plans to absorb the graphical union in 2006. The two Danish general unions (SID, largely organising unskilled men) and KAD (mainly women) will merge in 2005 and become the largest LO affiliate. Only the Swedish bluecollar union in the metal sector and the Finnish metalworkers' unions remain among the largest unions. These unions are important for taking the lead in wage formation while the Danish SID and Norwegian Fellesforbundet, as general or multi-sector unions, are not as tied to export-oriented industries.

In terms of sectoral coverage, union confederations in Continental Europe are still dominated by industrial sector unions. The metalworkers' unions remain the largest affiliates within the Italian CGIL and Spanish CC.OO, the second in size in the German DGB and Spanish UGT, and the third in Austria's ÖGB. At the same time, the new multi-sector industrial unions are prominent in the Dutch FNV and CNV as well as the Belgian CSC and the Swiss SGB. Nevertheless, public sectors and white-collar unions have gained in importance. Most prominently, Germany's largest DGB union, Verdi, was formed by a merger of public sector, postal, white-collar and media worker unions in 2001. Public employees' unions are second in membership size in both Dutch confederations. In the Austrian ÖGB the communal workers' union may find it difficult to catch up in size to equal the members of the planned merger of white-collar association (GPA) and metalworkers' union because the state employee union is more conservative politically and unlikely to join the communal workers' union. Large public sector organisations as well as transport workers' unions also take a prominent and strong role in the Southern European countries (as well as France), partly because of the more hostile labour relations and lower union density in the private sector.

\section{COLLECTIVE BARGAINING STRUCTURES AND WAGE MODERATION}

The main economic function of trade unions remains the negotiation of collective agreements to protect the wage and working conditions of its members, if not all employees. Where employers apply negotiated wages to all employees in order not to discriminate against non-unionised employees or where collective agreements are extended to all by the state, collective agreements are a public good (Olson, 1965) shared by those that are members of trade unions and those that do not actively support them. Because of collective action problems, trade unions may find it difficult to mobilise enough members and receive enough support in industrial disputes. As a consequence, they remain dependent on both the employers' interest in maintaining collective bargaining to avoid wage competition and on continued state support for collective bargaining (van Waarden, 1995). Bargaining coverage - the degree to which collective agreements apply to the dependent labour force-may exceed union density because employer associations are often better organised than unions or because of state extension of collective agreements to unorganised workers and firms (Calmfors et al., 2001; Traxler et al., 2001).

The degree of union fragmentation within and between union confederations also has important consequences for collective bargaining. For example, political unionism raises the question of representativeness: how many and which unions need to sign in order to validate an agreement? A strong coordinating confederation along with

(C) Blackwell Publishing Ltd. 2004. 
concentration in a small number of negotiating unions may ensure more effective wage bargaining, but it will also be more likely to take into account the variety of employee interests across different sectors, occupations and status groups. Furthermore, the more coordinated collective bargaining is, the wider will be the economic impact of such negotiations (Olson, 1982). In contrast, relatively small unions are able to pursue more sectionalist strategies with little impact on the overall economy.

Coordination across politically or functionally divided labour movements is particularly crucial for the success of tripartite concertation with governments and employers, thus inter-union coordination is an important precondition to establishing the legitimacy and representativeness of corporatist agreements. Social pacts often go beyond incomes policies that seek wage moderation and also may include a wide range of issues, such as adaptation of the bargaining system, social policy and labour market reforms (Fajertag and Pochet, 2000; Hassel, 2002b; Pochet, 2002). While tripartite negotiations usually give union confederations a special role, large dominating sectoral unions can also assume a de facto coordinating role, as in the frequent instances of pattern bargaining in Germany, Austria and Switzerland (Traxler and Kittel, 2000). In addition, bargaining cartels within or across union confederations can provide a coordinating role such as in Nordic union movements. In France and Southern Europe, supplementary local bargaining and weak multi-employer negotiations prevail even where social pacts occur (Visser, 2002).

As a consequence of decentralised bargaining and declining union membership and influence, bargaining coverage in Britain has fallen to a comparatively low level: from over 70 per cent in the early 1980s, the situation now is that barely more than every third employee is covered by an agreement (Table 2). Wage councils were also abolished in the 1980s. However, two recent legal changes have provided some institutional support for unions: the national minimum wage enacted by the Labour government in 1998 and the new union recognition procedure under the Employment Relations Act (1999). Additionally, the government has mainly implemented the pay review bodies' recommendations for public sector pay awards over the last four years. Furthermore, in 2002, strikes in the public sector (education, local government and most prominently in the fire service) over the gap between public and private sector pay and the modernisation of public services have contrasted with the relatively low level of strikes in the private sector. Collective agreements in the wider economy, largely negotiated at the firm level, have slightly exceeded both inflation and productivity gains (see Table 2).

In contrast to the decentralised bargaining in Britain, Irish wage bargaining has been highly centralised via three-year national agreements since 1987. Although bargaining coverage may also be relatively low in Ireland, in European terms, it is probably still more extensive than in Britain as union density is somewhat higher. Following a compromise between the Irish social partners, the Industrial Relations Amendment Act (2001) provides a new procedure for binding Labour Court recommendations, if voluntary advice by the Labour Relations Commission is of no avail. The earlier tripartite agreement, 'Programme for Prosperity and Fairness' (20002002), provided pay increases of 15.8 per cent over 33 months in three instalments. After difficult negotiations, the unions ratified the new agreement 'Sustaining Progress' in March 2003, although the agreement only lasted for half the proposed period. The pay settlement of 7 per cent will be implemented in three steps (over the first 18 months) with a six-month moratorium in the public sector. In addition, public sector wage scales are under review, based on the recommendations of the Public 


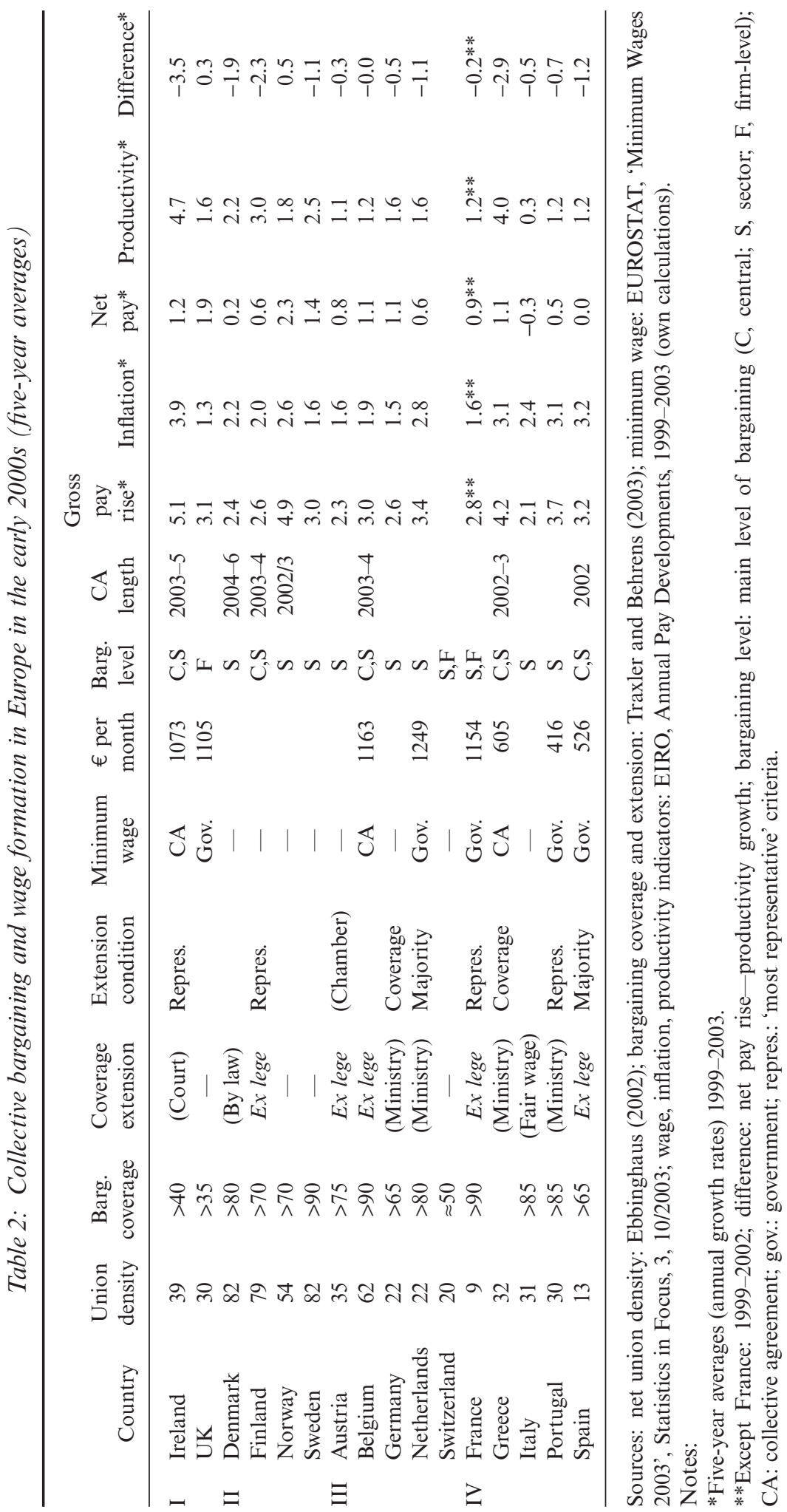


Service Benchmarking Body, although implementation will be contingent on reaching modernisation agreements. New negotiations during Stage Two are being conducted in the summer of 2004 following SIPTU's rejoining the ICTU bargaining team, while demanding wage increases in line with high inflation and productivity gains. In fact, Irish gross pay has grown considerably over the last five years, even though falling dramatically below the inflation plus productivity margin among all EU countries and Norway (see Table 2).

The institutional contexts and organisational preconditions for collective bargaining remain more favourable in the Nordic countries than elsewhere-the trade unions benefit from a high level of membership; the employer associations are well organised; sectoral if not central agreements are widespread; and bargaining coverage remains high (above 70 per cent) (Wallerstein and Golden, 2000). State mediation traditionally plays a supporting role in all Nordic countries except for Sweden, which developed voluntary and statutory mediation procedures following the industry-union agreement and complementary legislation of 1997 (Elvander, 2002). ${ }^{1}$ Multi-annual collective agreements are also dominant in the private sectors of Nordic countries: four years in Denmark (2000-03), three years in Sweden (2001-03), and two years in Norway (2002-03). Nearly every Finnish union signed the two-year central agreement (2003-04) in November 2002, thereby replacing the previous pact (2001-02). Firmlevel bargaining follows these central or sectoral agreements and the export-oriented manufacturing sector sets the trends for collective bargaining in other parts of the private sector and the public sector. The Finnish social partners also negotiate a central agreement, which mediates between the public and private sectors as well as between blue-collar and white-collar employees. Nevertheless, some private sector unions (about 10 per cent of all union members) have not signed the previous or current central agreement.

Although industry pay-setting has been the dominant Nordic model, the strong public sector unions at times diverge from the model. In Denmark, the local government unions - organised by a cartel of $65 \mathrm{LO}$ and non-LO unions - diverged from the agreement of the four big central government unions (including FOA, LO's third largest affiliate with 14 per cent) because of the contentious issue of more flexible 'new pay'. In Sweden, the blue-collar communal workers' unions (Kommunal, LO's largest union with 28 per cent) and the teacher unions (including TCO's second largest affiliate with 17 per cent) have negotiated higher pay rises, claiming to have fallen behind general wage development in the past. Divergence from the export industry norm and differentiation within the public sector is most common in Norway where white-collar and public sector unions received the highest wage increases.

Over the last five years (1999-2003) net pay increased very moderately in Denmark and Finland (less than 1 per cent), whereas it grew faster in Sweden (1.4 per cent) and very fast in Norway (2.3 per cent on the average and 3.1 per cent in 2002 alone). A new collective agreement in Danish industry provides for three-year targets on minimum pay limits and welfare benefits but delegates other pay issues to the firm level, while similar agreements were negotiated in other parts of the private sector. Finland's two-year agreement, which led to an increase in net pay by 1 per cent in 2003, will expire at the end of 2004. The 2004 bargaining round in Sweden led to a three-year

\footnotetext{
${ }^{1}$ The mediation agreement of 1997 (renewed in 1999) between SAF and LO introduced voluntary mediation in private manufacturing (including an advisory Economic Council for Industry). Similar agreements were negotiated in the public sector in 2000, and the Mediation Act of 2000 defines the statutory default regulation for the remaining 40 per cent of the labour force (Elvander, 2002).
} 
agreement ( 7.3 per cent in total costs, including working time cuts) in several industrial sectors, and the communal workers' unions signed a two-year agreement after a strike in 2003, which allows for substantial pay increases to be negotiated locally, notably for health and social care workers. In response to government concerns about Norwegian competitiveness (in particular inflation exceeding productivity increases by 0.5 per cent over the last five years), the social partners agreed a joint statement in January 2003 that wage growth 'must be seen to be sensitive to the challenges faced by export industry as well as the overall goal of full employment' (EIRO: NO0302105F). The outcome was that the 2004 bargaining round was of modest dimensions, although partly this was owing to government plans to introduce its own statutory occupational pensions instead of leaving the issue to negotiations at the industry level.

In all Nordic countries, negotiating employment-friendly, price-stable and equitable collective agreements - whether by centralised negotiations, sectoral pattern bargaining or via bargaining cartels - has proven to be increasingly difficult because of the concentration within large public sector unions; the eroding power of blue-collar industrial unions; the divergence of central and local public sector unions; the continuation of different peak associations; and the competition from and between professional unions. Moreover, Denmark and Norway also suffer from a high level of industrial disputes, at variance with their neighbours' declining strike trends (Stokke and Thörnqvist, 2001).

In Austria and Germany, collective bargaining occurs at the sectoral level (often limited to a region) with pattern-setting by the export sector, as in Nordic countries, although contracts tend to be negotiated annually. The metalworkers' union in Germany (IG Metall, the largest DGB affiliate until the Ver.di merger in 2001 and now a close second with 34 per cent) and in Austria (GMT, the third largest in ÖGB with 15 per cent) traditionally set the collective pay norms (Traxler et al., 2001). Their innovations also spread across the economy, such as the 2002 pay framework agreement in German metal manufacturing, negotiated after strike action, which overcomes the traditional separation of blue-collar and white-collar pay scales. Although in the case of Austria bargaining coverage in the private sector is nearly complete because of the compulsory affiliation of private employers to the Chamber of Commerce, bargaining coverage has eroded in post-unification Germany because of companies leaving employers associations or opting out of agreements. ${ }^{2}$ Both Austria and Germany experienced moderate net wage increases over the last five years (around 1 per cent) that did not keep up fully with productivity gains (see Table 2).

Increased decentralisation also provides a challenge to Germany's dual representative structure. Therein, unions negotiate wage agreements mainly beyond the firmlevel and statutory works councils (independent of union structures and without a right to strike), represent employee interests and implement non-wage regulation, but they do not engage in wage setting (Hassel, 2002a). The 2001 reforms of the German works council law have improved some representative rights, lowered the minimum thresholds, allowed easier election procedures for smaller establishments and have introduced gender representation provisions. However, despite initial high hopes, pos-

\footnotetext{
${ }^{2}$ In 2000, 70 per cent of all West German employees were covered by collective agreements (one in every 10 employees was covered by a firm-level agreement) while in the East coverage was as low as 55 per cent, of which one in every five employees was covered by a firm-level agreement (Kohaut and Schnabel, 2001). Although multi-employer bargaining remains important, there is an increasing trend towards its erosion and replacement by local bargaining (EIRO: DE0201299F) while employer associations suffer from membership losses or grant associate ('Ohne Tarifvertrag') membership to firms that wish to remain outside the associations' collective agreements.
} 
itive effects have not materialised in the 2002 workplace elections. There has been no significant increase in the number of works councils or in private sector employment coverage (Ellguth, 2003). Only one in every ten firms with five or more employees has a works council while about half of all private sector employees are represented by a works council (about 10 per cent less in the East), particularly in larger establishments. ${ }^{3}$ Efforts by the government and employers to discuss wage guidelines in the 'Alliance for Jobs' talks failed and have been terminated while the government has pushed through its Reform Agenda 2010, which aims at a major overhaul of labour market policies and cuts in welfare benefits, despite the protests of trade unions. IG Metall suffered from a major defeat in its campaign to introduce working time reductions in Eastern German steel and manufacturing sectors, calling off its strike action in the summer of 2003. This major setback was followed by internal conflicts over the leadership succession, settled by a compromise between the more radical and moderate wings. Then the 2004 metalworkers' pilot agreement in Southwest Germany agreed to rather moderate wage increases for the next two years and a conditional option for an upwards extension of the 35-hour working week.

Wage moderation has for long been the hallmark of Dutch bargaining (Hemerijck, 2003; Visser and Hemerijck, 1997) while a centralised incomes policy is the key feature in Belgium (Arcq and Pochet, 2000). As in Germany, Dutch wages are set mainly at the sectoral level (two-thirds of employees are covered, including the public sector); some agreements are legally extended (about 7 per cent coverage) and are increasingly negotiated at the firm level (about 12 per cent of employees). Recently, Dutch employers and liberal politicians have questioned legal extension given the low representativeness of unions (with union density at only 22 per cent) and have demanded further decentralisation, although many multi-employer agreements are merely framework deals. At the end of 2002, concerns about an erosion of the Dutch 'polder model' led to the first 'social agreement' in a decade, with the main unions (FNV and CNV) committing themselves to wage moderation in the 2003 bargaining round in exchange for reduced social contributions and other concessions by the government. In terms of net wage growth, wages in the Netherlands have almost stagnated over the last five years, and wages fell considerably behind productivity increases ( -1.1 per cent). As in Germany, excessive pay for managers, while wage moderation and welfare reform burden ordinary wage and salary earners, has provoked public debate. Nevertheless, the incoming Christian-Liberal government was able to settle a tripartite agreement in October 2003 that froze pay for the following two years (2004-05) in return for more moderate cuts in welfare benefits.

Belgium has achieved relative pay moderation (on the average 1.1 per cent of net wage growth, although not exceeding productivity gains), thanks to its coordinated incomes policy through biennial national framework agreements followed by sectoral agreements in odd years and company-level follow-up negotiations in even years. In January 2003, a new deal for two years was ratified by the social partners who continued to follow a competitive pay norm (5.4 per cent over two years) in line with its neighbours' (France, Germany and the Netherlands) labour costs and automatic

\footnotetext{
${ }^{3}$ According to the German IAB-Betriebspanel survey, among private sector firms (with five or more employees) 48 per cent (West 50 per cent, East 40 per cent) of employees were covered by a works council in 2002, that is, no change from 1998 (except for the East at 38 per cent). Coverage increases with size of establishment: $5-50$ employees $=12$ per cent; $51-100=46$ per cent; $101-199=73$ per cent; $200-500=86$ per cent; $500+=96$ per cent - although coverage is somewhat lower in the East, particularly in firms with 201-500 employees (78 per cent) (Ellguth, 2003: 194).
} 
indexation as stipulated by law. Within the tripartite council structure, some 500 agreements (at the subsectoral level) implement these norms. However, no agreement was reached on the planned abolition of distinctions between white-collar and bluecollar status that would have improved the employment rights of the latter group. One obstacle is that union organisations are still divided along the 'collarline' in the private sector: the white-collar union is the largest Christian union (17 per cent) and the Socialists represent the second largest ( 23 per cent) within the main union confederations. The influence of trade unions does not stop at bargaining, however, as they are also involved in workplace representation and welfare benefit administration.

Because of bargaining on working time reductions in return for wage moderation, wage growth has been relatively moderate in France since 1999, but bargaining has shifted back to pay issues from 2002 onwards. The state has a major impact on bargaining through the requirement for firm-level negotiations, minimum wage provisions and the legal extension of collective agreements. Thus, despite the very low union density, decentralised bargaining structure and relatively fragmented employer associations, 90 per cent of French employees are covered by agreements securing at least minimum standards. French annual net pay increases have been modest $(0.9$ per cent) over the last four years (1999-2002). Remaining only slightly below productivity gains, this may be taken as a considerable achievement, given the relatively weak union movement and decentralised bargaining structure, as well as in comparison to the Southern European union movements that fared much worse (see Table 2).

As in France, bargaining coverage is surprisingly high in Spain (above 65 per cent), Portugal (above 80 per cent) and Italy (around 90 per cent), partly as a result of intersectoral agreements that provide a framework for wage bargaining at the sectoral, regional and local levels. In Spain, the 2002 intersectoral agreement between the main employers and union confederations set a minimum for inflation-proof wage increases (extended in 2003 for the following year), while a pact between the government and public sector unions in 2002 promised a net wage increase of 2.5 per cent over 200304 in return for reforms in public administration. Although Portuguese tripartite concertation under the Socialist government has excluded wage bargaining in recent years, gross wages increased largely in line with inflation while net wages remained very low. The new liberal-conservative government, elected in March 2002, has embarked on a more austere course with a partial pay freeze on public sector wages while the labour market bill will weaken unions in collective bargaining as agreements expire if not renewed by all parties (Naumann in ETUI, 2003). In Greece, a central framework agreement for 2002-03, signed in April 2002, set gross wage increases at 5.4 per cent including a cost of living adjustment from the last agreement. Greek unions have demanded higher increases in the 2004 wage rounds in order to close the wage gap with other EU member states. In Italy, collective bargaining is conducted largely at the sectoral and regional level in a two-tier bargaining process of interfirm and firm-level bargaining, with the metalworking sector often taking the lead and the public sector agreements establishing precedents on non-wage issues. The most recent 2003-06 agreement in metal manufacturing has introduced new job classifications but was not signed by the largest affiliate of the CGIL, FIOM, making implementation a contentious issue. Among the four Southern countries (see Table 2), net wage increases have remained very limited over the last five years, except in Greece (1.1 per cent), and fell far behind productivity gains, particularly in Greece (almost 3 per cent). Despite the institutional support for collective agreement, relatively decentralised

(C) Blackwell Publishing Ltd. 2004. 
bargaining and fragmented union structures have led to wage moderation because of pressures from employers and government.

Negotiated reforms of social security have remained high on the agenda in all Southern European countries as well as in France. After the re-election of Jacques Chirac as president and the election of a new Centre-Right government in 2002, the government launched new pension proposals while the trade unions signed a joint declaration and demonstrated to safeguard pension rights (such as a statutory retirement age of 60). The Spanish social partners and government signed an agreement on flexible pensions in 2001 enacted in 2002. However, social dialogue on unemployment benefit reform broke down in 2002 and the government withdrew its unilateral proposal after a political strike. In Portugal, social dialogue resulted in several agreements on health and safety, training and pension contributions in 2001. Yet after the shift in government to the right, concertation on the proposed Labour Code was deemed insufficient by the Portuguese CGTP union confederation, which organised a general strike in December 2002. Tripartite concertation on social policy matters has gained in importance within the Greek Economic and Social Council as well as informally. A bill establishing a new National Employment Council and a parallel social security council was proposed as a result of the desire among social partners for more effective concertation on policy issues.

\section{CONCLUSION}

The changing organisational landscape among European unions - in particular the concentration in and sectoral location of the large unions - has had important consequences for collective bargaining coordination and leadership. The trend towards large super-unions has led to considerable concentration over the last two decades, although there are important cross-national differences. German, Dutch and Austrian super-unions in both public and private sectors (will) dominate the sectoral negotiations, replacing the traditional dominance of metalworker unions in wage bargaining. The Nordic union movements have also restructured towards larger unions while the weight has shifted towards the public sector as well as white-collar organisations. British unions and (to a lesser degree) Irish unions as well as the politically divided union movements in France and other Southern European countries remain more fragmented. Where decentralisation prevails, as particularly in Britain, bargaining coverage is relatively low and dependent on the representational strength of unions while in some Continental European countries the better organised employers and extensive legal provisions guarantee a more encompassing coverage than could be expected based on low membership density and fragmented union movements. With the exception of Nordic and Belgian unions with high union membership, the other union movements are also dependent on employer strategies and state support to regulate labour relations via bargaining.

The review of bargaining practices using pay indicators over the last five years reveals a common pattern of moderate wage bargaining across most negotiation systems. Annual net pay over this period has remained stagnant (below 0.7 per cent) in Denmark, Finland, Italy, Portugal and Spain, and very moderate (below 1.5 per cent) in all other countries, except in Britain (1.9 per cent) and Norway (2.3 per cent). This has been partly because of central or private sector incomes policies that set moderate wage targets over several years (Belgium, Denmark, Finland, Greece, 
Ireland, Norway, Spain); pattern-wage bargaining in export sectors (Austria, Germany, Italy, Netherlands); or sheer market forces (Britain, France, Portugal). The tripartite social pacts of the 1990s, however, are less frequently employed and effective today than in the run-up to EMU. Thus the German tripartite talks have ended without any success in coordinating wage policies, as wage bargaining under Irish tripartite consultation now lasts for only half of its former three-year period and the Belgian process has also been unable to solve some of the more pressing issues. Moreover, the considerable failure to maintain net wages in line with productivity growth in all but a few countries has increased union frustration with wage moderation strategies, particularly in those countries that have not seen an improvement in employment over recent years.

\section{References}

Arcq, E. and P. Pochet (2000), 'Toward a New Social Pact in Belgium?', in G. Fajertag and P. Pochet (eds), Social Pacts in Europe: New Dynamics (Brussels, ETUI).

Calmfors, L., A. Booth, D. Checchi, R. Naylor and J. Visser (2001), 'Part I: The Future of Collective Bargaining in Europe', in T. Boeri, A. Brugiavini and L. Calmfors (eds), The Role of Unions in the Twenty-First Century. A Report to the Fondazione Rodolfo Debenedetti (Oxford, Oxford University Press) pp. 1-139.

Ebbinghaus, B. (2002), 'Trade Unions' Changing Role: Membership Erosion, Organisational Reform, and Social Partnership in Europe', Industrial Relations Journal, 33, 5, 465-483.

Ebbinghaus, B. (2003), 'Ever Larger Unions: Organisational Restructuring and Its Impact on Union Confederations', Industrial Relations Journal, 34, 5, 446-460.

Ebbinghaus, B. and A. Hassel (2000), 'Striking Deals: Concertation in the Reform of Continental European Welfare States', Journal of European Public Policy, 7, 1, 44-62.

Ebbinghaus, B. and J. Visser (2000), Trade Unions in Western Europe Since 1945 (Handbook and CD-ROM) (London, Palgrave/Macmillan).

EIRO (1997- ), EIROnline, http://www.eiro.eurofound.eu.int

Ellguth, P. (2003), 'Quantitative Reichweite der betrieblichen Mitbestimmung', WSI Mitteilungen, 2003, 3, 194-199.

Elvander, N. (2002), 'The New Swedish Regime for Collective Bargaining and Conflict Resolution: A Comparative Perspective', European Journal of Industrial Relations, 8, 2, 197-216.

ETUI (ed.) (2003), Collective Bargaining in Europe in 2002 (Brussels, ETUI) (http:// www.etuc.org/etui).

Fajertag, G. and P. Pochet (eds) (2000) Social Pacts in Europe: New Dynamics (Brussels, ETUI).

Hassel, A. (2002a), 'The Erosion Continues: Reply', British Journal of Industrial Relations, 40, 2, 309-317.

Hassel, A. (2002b), 'A New Going Rate? Co-ordinated Wage Bargaining in Europe', in P. Pochet (ed.), Wage Policy in the Eurozone (Brussels, P.I.E.-Peter Lang) pp. 149-173.

Hemerijck, A. (2003), 'A Paradoxical Miracle: The Politics of Coalition Government and Social Concertation in Dutch Welfare Reform', in S. Jochem and N. A. Siegel (eds), Konzertierung, Verhandlungsdemokratie und Reformpolitik im Wohlfahrtsstaat (Opladen, Leske \& Budrich) pp. 232-270.

Kjellberg, A. (1998), 'Sweden: Restoring the Model?', in A. Ferner and R. Hyman (eds), Changing Industrial Relations in Europe (Oxford, Blackwell) pp. 74-117.

Kohaut, S. and C. Schnabel (2001), Tarifverträge - nein danke!? Einflussfaktoren der Tarifbindung west- und ostdeutscher Betriebe (Nürnberg, Universität Erlangen-Nürnberg).

Molina, O. and M. Rhodes (2002), 'Corporatism: The Past, Present, and Future of a Concept', Annual Review of Political Science, 5, 305-331.

Olson, M. (1965), The Logic of Collective Action: Public Goods and the Theory of Groups, 2nd edn. (Cambridge, MA, Harvard University).

(C) Blackwell Publishing Ltd. 2004. 
Olson, M. (1982), The Rise and Decline of Nations (New Haven, London, Yale University Press). Pochet, P. (ed.) (2002), Wage Policy in the Eurozone (Brussels, P.I.E.-Peter Lang).

Rhodes, M. (2001), 'The Political Economy of Social Pacts: "Competitive Corporatism" and European Welfare Reform', in P. Pierson (ed.), The New Politics of the Welfare State (New York, Oxford University Press).

Stokke, T. A. and C. Thörnqvist (2001), 'Strikes and Collective Bargaining in the Nordic Countries', European Journal of Industrial Relations, 7, 3, 245-267.

Traxler, F. and M. Behrens (2003), 'Collective Bargaining Coverage and Extension Procedure', EIRO, TN0212102S.

Traxler, F. and B. Kittel (2000), 'The Bargaining System and Performance. A Comparison of 18 OECD Countries', Comparative Political Studies, 33, 3, 245-267.

Traxler, F., S. Blaschke and B. Kittel (2001), National Labour Relations in Internationalized Markets. A Comparative Study of Institutions, Change, and Performance (Oxford, Oxford University Press).

Visser, J. (2002), 'Unions, Wage Bargaining and Co-ordination in European Labour MarketsThe Past Twenty Years and the Near Future', in P. Pochet (ed.), Wage Policy in the Eurozone (Brussels, P.I.E.-Peter Lang) pp. 39-77.

Visser, J. and A. Hemerijck (1997), 'A Dutch Miracle': Job Growth, Welfare Reform, and Corporatism in the Netherlands (Amsterdam, Amsterdam University Press).

van Waarden, F. (1995), 'Employers and Employers' Associations', in J. Van Ruysseveldt, R. Huiskamp and J. V. Hoof (eds), Comparative Industrial and Employment Relations (London, Sage) pp. $68-108$.

Waddington, J. and R. Hoffmann (2000), 'Trade Unions in Europe: Reform, Organisation and Restructuring', in J. Waddington and R. Hoffmann (eds), Trade Unions in Europe. Facing Challenges and Searching for Solutions (Brussels, ETUI) pp. 27-79.

Wallerstein, M. and M. Golden (2000), 'Postwar Wage Setting in the Nordic Countries', in T. Iversen, J. Pontusson and D. Soskice (eds), Unions, Employers, and Central Banks (New York, Cambridge University Press) pp. 107-137. 